\title{
Pleistocene Vertebrate Faunas in the Ryukyu Islands: Their Migration and Extinction
}

\author{
Hiroyuki OTSUKA \& Akio TAKAHASHI Department of Earth and Environmental Sciences, \\ Faculty of Science, Kagoshima University, Kagoshima 890-0065, Japan
}

\begin{abstract}
Results of present studies on the stratigraphic levels and the paleontological analysis of terrestrial vertebrate fossils in the Ryukyu islands furnish valuable clues and considerations as to the history and age of animal migration from the continent to its neighboring islands. To date, four diagnostically different stratigraphic levels containing Late Miocene to latest Pleistocene vertebrate fossils have been delineated in the islands. Geological and paleontological data suggest that the area of the Ryukyu Islands has been repeatedly connected to the Asiatic Continent and each land connection has been followed by migration of characteristic terrestrial vertebrates from the continent.

Among the fossil assemblages found in these four different stratigraphic levels, those from Level 2 (Early Pleistocene) are known to occur in shallow marine deposits underlying the Early to Middle Pleistocene Ryukyu Group. They are considered to be immigrants from either the latest Pliocene Renzidong fauna (Jin \& Zheng, 1998; Huang, 1998; Jin et al., 1999) in Anhui Province or the Wushan hominid fauna (Huang et al., 1991) in Sichuan Province, both located in Central China, during the second land connection. This assemblage may be regarded as the oldest post-Miocene fauna and might include the ancestors of the Pleistocene fossil and living endemic terrestrial vertebrate faunas of the Ryukyu islands.

Another important species of fossil assemblage of terrestrial vertebrates in the islands is closely associated with the latest Pleistocene fissure and cave deposits developed within the Ryukyu Group or coeval terrace deposits (Level 4). These assemblages are considered to be mixed faunas that migrated from the Asian mainland to the islands during different periods of land connection in the past. Terrestrial vertebrate fossils from this level include large mammal (deer) and giant tortoise that became extinct at the end of the latest Pleistocene. However, descendants of other animals including mammals, amphibians and reptiles, are still living in the islands forming characteristic insular endemic fauna.
\end{abstract}

Key words: Ryukyu Islands / terrestrial fossil vertebrates / land connection / endemism / Pleistocene

The Ryukyu Islands, stretching from the Japanese mainland of Kyushu to Taiwan, is one of the most important paleontological fields in the world as far as insular animal evolution is concerned. It offers abundant occurrences of fossils as well as a spectacular diversity of extant endemic species, whose ancestors were escaped extinction during the latest Pleistocene.

To date, the Pleistocene deposits in the Ryukyu Islands have yielded numerous characteristic fossils of terrestrial vertebrates that migrated from continental Asia to the islands during several periods of temporary land connection (mostly Pleistocene). Among vertebrate fossils, the descendants of large mammals (deer and elephant ) were isolated in the islands for more than $\mathbf{1 . 5}$ million years, and in the process, became the major components of the Ryukyu's characteristic fossil fauna. These 


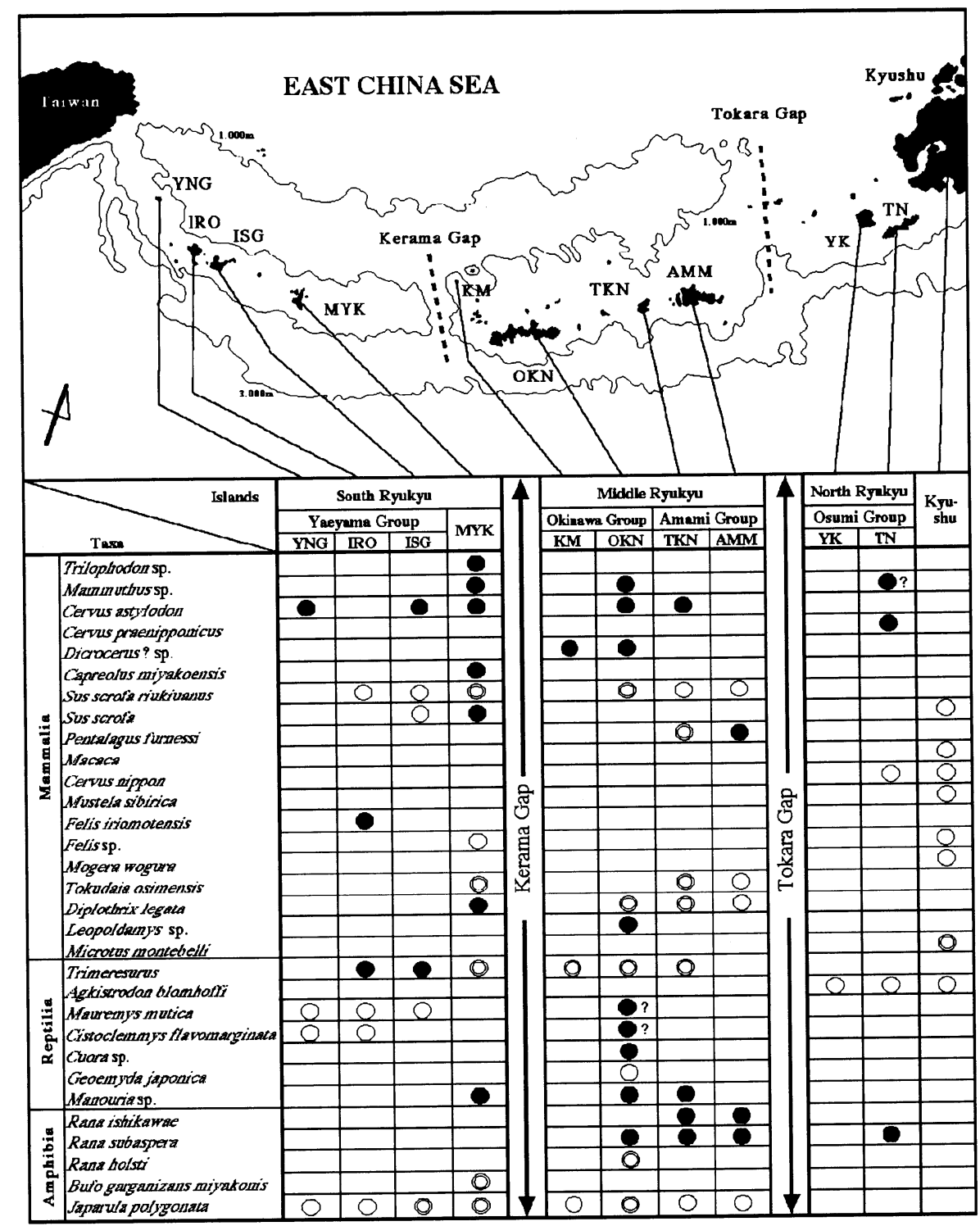

Fig. 1. Geographic distribution of some selected terrestrial vertebrates in the Ryukyu Islands. (O; fossil, $\bigcirc$; living, (); fossil and living). Abbreviations: YNG; Yonaguni Is., IRO; Iriomote Is., ISG; Ishigaki Is., MYK; Miyako Is., OKN; Okinawa Is., TKN; Tokunoshima Is., AMM; Amami-oshima Is., YK; Yakushima Is., TN; Tanegashima Is.

taxa became extinct near the end of the latest Pleistocene; however, other medium to small-sized mammals (wild rabbits and rats), amphibians (frogs and newts) and reptiles (turtles, snakes and lizards) have survived in the islands, forming the present endemic faunas (Ota, 1998). Based on the distribution of these endemic species, the zoogeographical boundary known as Watase Line was drawn along the Tokara Strait (Okada, 1927). The terrestrial animal assemblages on the southern side 


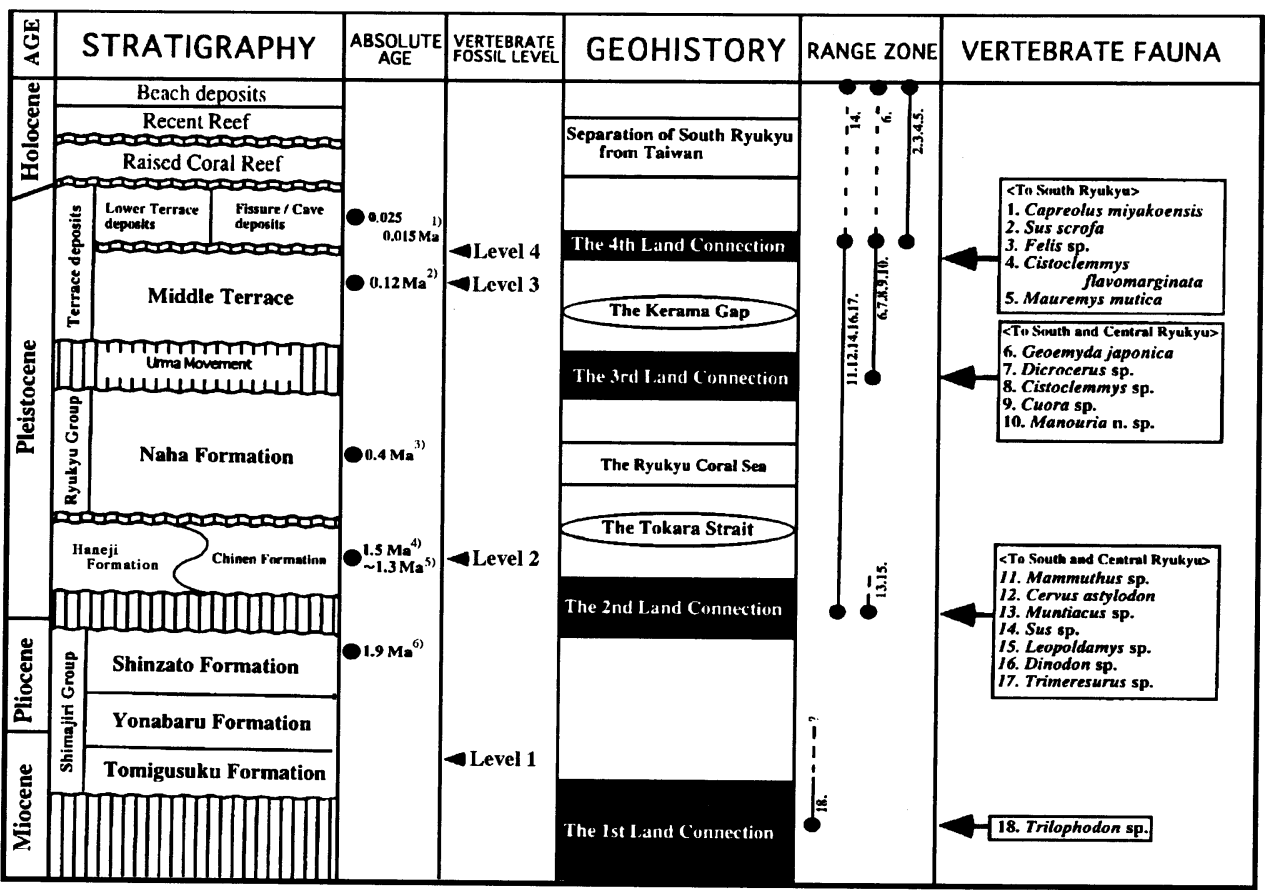

Fig. 2. Stratigraphy, geohistory and fossil terrestrial fauna of the Ryulyu Islands. 1) Takai \& Hasegawa, 1971; Suzuki, 1975; Hasegawa, 1980. 2) Age of the highest sea level of Last Intergracial age in Japan. 3) Kaneko \& Ito, 1995. 4) Otsuka, MS. 5) Honda et al., 1993, 1994; Kaneko \& Ito, 1995. 6) Natori, 1976; Ujiie, 1985; Nakagawa et al., 1982; Saito, 1984; Tanaka \& Ujiie, 1984 (first appearance of Gl. truncatrinoides).

of this line (Central and South Ryukyu) are characterized by endemic animals including the Amami rabbit (Pentalagus furnessi), two native rats (Rattus legata, Tokudaia osimensis), wild cat (Felis iriomotensis) and a poisonous snakes. They show striking differences from animal assemblages found on the northern side of the line (North Ryukyu and mainland Japan). It is due mainly to these dissimilarities that the zoogeographic boundary between the Palearctic and Oriental regions (Wallace, 1876) was drawn along this line (Brauns, 1884; Okada, 1927), thus subdividing the Ryukyu Islands.

To know the origin of the terrestrial vertebrates of the Ryukyu Islands, geological and paleontological data are indispensable. In the Ryukyu Islands, terrestrial vertebrate fossils occur in four major stratigraphic levels (Otsuka, 1998) as shown in Fig. 2. The lowermost level corresponds to the Late Miocene shallow marine deposit (Shimajiri Group), while the uppermost level belongs to the latest Pleistocene fissure and cave deposits developed mainly in the Early to Middle Pleistocene Ryukyu Group or in the Late Pleistocene terrace limestone beds. The uppermost level contains extinct deer and large tortoises, wild boars, rats, wild rabbits, frogs, poisonous snakes and other vertebrates which are believed to be descendants of earlier immigrants that migrated from continental Asia during different periods of land connection.

The four diagnostic stratigraphic context containing vertebrate fossils found in the Miocene and Pleistocene deposits of the Ryukyu Islands are as follows: 
1. Level 1 (Latest Miocene; ca. 6 Ma B.P.)

Lowest level of the Miocene Shimajiri Formation in Miyako Island

2. Level 2 (Early Pleistocene; ca. 1.5 - 1.3 Ma)

The Haneji Formation in Okinawa Island; The Katanoyama member of the Masuda Formation

in Tanegashima

4. Level 3 (Late Middle Pleistocene; ca. $0.12 \mathrm{Ma}$ )

Middle terrace deposits distributed in Okinawa and Kume Island

5. Level 4 (latest Pleistocene; $0.025-0.015 \mathrm{Ma}$ )

Many fissure and cave deposits in the Ryukyu Islands ranging geographically from Tokunoshima to Yonaguni Islands.

\section{THE LAND CONNECTIONS AND THE STRATIGRAPHIC LEVELS CONTAINING TERRESTRIAL VERTEBRATE FOSSILS IN THE RYUKYU ISLANDS}

Most of the terrestrial vertebrate fossils that occurred in different stratigraphic levels in the Ryukyu Islands. These vertebrate fossils occur mostly in cave or fissure deposits. To date, the following four levels of terrestrial vertebrates are known in the Ryukyu Islands.

\section{Level 1 (Late Miocene; ca.6 Ma):}

In the Ryukyu Islands, marine deposits of the Middle to Late Miocene are scarcely known. This implies that the Ryukyu Islands and its surrounding sea area might had been exposed above the sea level and possibly been connected to the southern part of Asia during that period (The First Land Connection).

The Shimajiri Group, which comprises mainly offshore marine mudstones and sandstones, occurs in the islands of the Central and South Ryukyus and on the surrounding sea floor (Hanzawa, 1935; Aiba \& Sekiya, 1979). On Miyako Island, this group is exposed in a narrow area along the northeastern margin of the island. It is composed mainly of mud and sand layers and attains a maximum thickness of more than 600 meters. The planktonic foraminiferal zones ranging from N16 to N22 in Blow's (1969) scheme have been delineated this group (Ujiie \& Oki, 1974). From these data, the Shimajiri Group in Miyako Island can be dated to the Late Miocene to Early Pleistocene.

On Miyako Island, a molar of Trilophodon sp. was recorded in the lowest level of the Shimajiri Group (Level 1) (Hasegawa et al., 1973). This is the first occurrence of Stegodontinae in the Ryukyu Islands, which implies that the Late Miocene Ogawa Fauna (Shikama and Otsuka, 1971), known from mainland Japan, is traceable also in the South Ryukyus (Otsuka, 1983). The migration probably took place during the time of the First Land Connection.

\section{Level 2 (Early Pleistocene; ca. 1.5 - 1.3 Ma) and the Second Land Connection:}

During the Early Pleistocene, the Ryukyu Islands were connected to Asian mainland, forming a peninsula like "landspan"(Iturralde-Vinent \& MacPhee, 1999) extending eastward from north Taiwan. However, this "Ryukyu Peninsula" did not connect to either mainland Kyushu or the Osumi insular 
group (the islands of Tanegashima and Yakushima) (the Second Land Connection)(Kizaki \& Oshiro, 1977; Kimura, 1966a, b). This land configuration is supported by recent discoveries of terrestrial vertebrate fossils in Okinawa Island.

1) In Okinawa island, the Early Pleistocene terrestrial vertebrate assemblage known as the Imadomari-Akagimata fossil assemblage (Otsuka, 1998) occurs in the shallow marine and lacustrine deposits of the Haneji Formation (Noda, 1971) underlying the Early to Middle Pleistocene Ryukyu Group (Level 2 ). This Haneji Formation is typically distributed in the environs of North of Nago City, Motobu Peninsula of the island, and nearly corresponds to the Nakoshi Sand of MacNeil (1960). The bone bed was dated as $1.5 \pm 0.3 \mathrm{Ma}$ by fission-track method. This assemblage, which is considered to be the oldest fauna of terrestrial vertebrates in the Ryukyu Islands, includes the ancestral form of the endemic Ryukyu deer (Cervus astylodon = Ryukyu-deer), Muntiacus sp., large rodent (= Leopoldamys n. sp.), turtle (= ?Mauremys sp.) and land snakes (Trimeresurus $\mathrm{sp}$. and ?Dinodon $\mathrm{sp}$. ). Furthermore, there is a very fair possibility of wild boar (Sus sp.) yield in Level 2, judging from the occurrence of isolated pig molars in float.

The descendants of animals in this stage are represented by Ryukyu deer (= Cervus astylodon) which flourished over the entire Ryukyu Islands during Pleistocene and finally became extinct some time in the late Pleistocene. Despite this, many other terrestrial vertebrates have survived and are still living in the islands including an endemic wild boar (Sus riukiuanus) and snakes (Trimeresurus and Dinodon).

The Imadomari-Akagimata fossil assemblage, also described as the Cervus astylodonLeopoldamys fauna, is closely related to either the late Pliocene vertebrate fauna of Renzidong in Fanchang, Anhui Province (Jin \& Zheng, 1998; Jin et al., 1999; Huang, 1998, 1999) or the Wushan hominid site in Wushan, Sichuan Province, both located in Central China (Huang et al., 1991) and can be identified by the presence of Cervus (Metacervulus) capreolinus, Leopoldamys sp. and Sus sp. in the latter two faunas. Cervus (Metacervulus) astylodon (Matsumoto), a representative fossil mammals of the Ryukyu Islands and also known for its systematic position to the genus Metacervulus (Tokunaga \& Takai, 1938), resembles the Chinese species Metacervus capreolinus in terms of morphological characteristics. Thus, there is a very fair possibility that Cervus astylodon and Metacervulus capreolinus can be synonymized.

Migration of the Wushan or the Renzidon fauna from central China to the Ryukyu Islands possibly took place during the Second Land Connection through the "Ryukyu Peninsula". However, paleontological data showed that the Cervus astylodon-Leopoldamys fauna and other terrestrial vertebrates of the Middle to Late Pleistocene were not able to cross the Tokara Strait (= Tokara Gap). In other words, the Watase Line was already fixed in the area of Tokara Strait before the arrival of the C. astylodon-Leopoldamys fauna in the Amami insular groups during the Early Pleistocene (Otsuka \& Kuwayama, 2000).

2) The Ishikawa's frog (= Rana ishikawae) is one of the endemic amphibians that inhabit the islands of Okinawa and Amami-oshima. Recently, a fossil of this species together with a number of fossil fishes, mammals and plants (Otsuka \& Nakamura, 1990; Otsuka \& Noro, 1990; Otsuka, 1990; Yabumoto \& Ueno, 1990; Uemura, 1990; Otsuka \& Kuwayama, 2000) was recovered from the Early Pleistocene Katanoyama member of the Masuda Formation (dated as $1.3 \pm 0.2$ Ma.B.P. by fission- 
track method) in Tanegashima Island of the Osumi insular group. From this discovery, it can be inferred that the terrestrial vertebrates, including the ancestor of the Ishikawa frog, may have crossed the land bridge from the Amami insular group to the island of Tanegashima during deposition of the Katanoyama member. This would have occurred before the migration of the Cervus astylodonLeopoldamys fauna to the Amami insular group from the south (Otsuka \& Kuwayama, 2000). In other words, the migration of the ancestor of the Ishikawa's frog from Amami-oshima to the Tanegashima area could have occurred just before the fixation of Watase Line during the early Early Pleistocene. This is in good agreement with the geological evidence that there were notable regression phases around the Ryukyu Islands from the Late Pliocene to Early Pleistocene after the sedimentation of the Shimajiri Group.

3) Moreover, in the southern extremity of Okinawa Island, a molar of an elephant described as Paleoloxodon? sp. (Nohara \& Hasegawa, 1973), has been recorded from the Middle Pleistocene Naha Limestone, lower part of the Ryukyu Group. As pointed out by the original authors, the molar is incompletely preserved, and therefore a precise account of its position in Elephantidae is nearly impossible. However, Kamei \& Otsuka (1981) regarded it as archetypal mammoth (Mammuthus), common genus in the Early Pleistocene of mainland Japan and Taiwan. Although this molar was embedded in the limestone as "gravel", it is possible that the elephant could have migrated to the island of Okinawa from the north before the appearance of the Tokara Gap (= Watase Line ), which is the product of marine transgression that formed Ryukyu Coral Sea. Also, Mammuthus from the Late Pleistocene cave deposits on the island of Miyako (Level 4) may be considered as descended from the early immigrants that migrated southward during the Early Pleistocene, together with ancestors of the Okinawan elephant.

\section{Level 3 (late Middle Pleistocene; ca. 0.18 - 0.13 Ma) and the Third Land Connection:}

In Kume Island of the Okinawa insular group, molars of Dicrocerus? sp. have been identified in shallow marine deposits formed probably at the time when the sea reached its highest level during the Middle Pleistocene (ca. 0.012 Ma). This is the first recorded appearance of this deer in the Ryukyu Islands. In addition to fossils of giant tortoise (Manouria sp.), two kind of box turtles (= Cistoclemmys sp., Cuora sp.) and Geoemyda japonica also occur in latest Pleistocene fissure deposits in Okinawa and Amami insular group. From this reason, they are considered as members of the Cervus astylodonManouria fauna. Since these chelonians have never been discovered in Level 2, there is a large possibility that Dicrocerus? sp. and land tortoise endemic to the Ryukyu Islands could have migrated from the continent to Central Ryukyu through "Ryukyu Peninsula" but could not cross the Tokara strait (Tokara Gap).

Kizaki \& Oshiro (1977) and Kimura (1996a,b) summarized concepts of crustal movement and land configuration in the environs of the Ryukyu Islands at the end of the Middle Pleistocene as follows: Due to regression and uplifting of the Ryukyu Coral Sea during the Middle Pleistocene, the area of the Ryukyu Islands was widely exposed above sea level, and the Yaeyama insular group were connected to the lowland area of South China through Taiwan. This resulted in the formation of a long and narrow peninsula extending to the Okinawa insular group, but not as far as the Amami insular group in Central Ryukyu. During the latter half of this event, an intense block movement called the "Ulma Movement" occurred in the Ryukyu Islands area, resulting in the formation of the Kerama gap 
(Okinawa Quaternary Research Group, 1976).

Judging from the occurrence of Dicrocerus? sp. and endemic to the Okinawa insular group as Manouria sp., Geoemyda japonica (= Ryukyu-yamagame), Cistoclemmys sp. and Cuora sp. could have migrated from the continent to Central Ryukyu through the "Ryukyu Peninsula" before the formation of the Kerama gap but could not reach the Amami insular group beyond the Tokara Gap .

\section{Level 4 and the Fourth Land Connection (latest Pleistocene; ca. 0.26 - 0.15 Ma; Würm glacial):}

The fossils of terrestrial vertebrates from Level 4 are commonly found in the Late Pleistocene fissure and cave deposits developed in the Early to Middle Pleistocene Ryukyu Group (limestone, sand and red clay) in the Ryukyu Islands. They are more abundant and well preserved than vertebrate fossils found in other levels. More than 100 fossil localities are known in the islands of the Central and South Ryukyus, ranging geographically from Yonaguni in the Yaeyama insular group to Tokunoshima in the Amami-oshima insular group (Oshiro \& Nohara, 1977; Otsuka \& Hasegawa, 1973; Otsuka, 1980, 1990; Tomida \& Otsuka, 1993; Oshiro, 1994, etc.). The fossils of terrestrial vertebrates from this level have different antecedents in each island and their differences presumably reflect from varied environmental conditions during each stage of land connection.

Terrestrial vertebrate assemblages in the Central Ryukyus (Okinawa and the Amami insular groups) are possibly descendants of propagules that migrated from the continent to the islands at the time of third and fourth land connections. They are grouped as the Cervus astylodon-Manouria fauna (Otsuka, 1998). Those fossil assemblages found in the South Ryukyu (Miyako and Yaeyama insular groups), on the other hand, can be considered as mixed faunas comprising the descendants of the Early to Middle Pleistocene immigrants and other animal assemblages at the time of the Fourth Land Connection in the Late Pleistocene.

Also during the Late Pleistocene, the area of the South Ryukyu (Yaeyama and Miyako insular groups) was connected to the marginal lowland area of the Asian mainland through North Taiwan (Kimura, 1996a,b). By this land connection, mammals of woodland and grassland habitats (Sus scrofa) migrated to South Ryukyu accompanied by other group of mammals (Felis sp., Capreolus miyakoensis, Microtus fortis, etc.) that migrated southward from northeastern Asia (Hasegawa, 1985; Hayashi, 1985; Kaneko, 1985; Kawashima et al., 1985; Zhen \& Hasegawa, 1985) and eventually mixed with other earlier immigrants (Mammuthus shigensis, Rattus legata, C. astylodon). This group of immigrant taxa resulted in the formation of a characteristic fossil assemblage of Miyako vertebrates that could not reach Okinawa Island because of the existing the Kerama Gap.

1) In Okinawa, Ie and Kume of the Okinawa insular group, there are a number of fossil sites containing terrestrial vertebrates that belong to Level 4. In particular, numerous fossils of mammals, reptiles, amphibians and birds have been collected from fissure and cave deposits developed in limestone rocks (Oshiro \& Nohara, 1977; Hasegawa \& Oshiro, 1981; Oshiro, 1994; Nohara et al., 1997, 1999).

As a whole, the vertebrate fossil assemblages from these islands may be regarded as the Cervus astylodon-Manouria fauna (Otsuka, 1998) and are inferred to be mixed assemblages of animals having different antecedents. That is to say, the originators of various lineages migrated to the island during the period of the second and third land connections.

The Minatogawa vertebrate assemblage is representative fossil from Level 4 in the Okinawa 
Island. This assemblage includes Minatogawa man, excavated from fissure deposits exposed at the Minatogawa quarry in southeast Okinawa (Suzuki, 1975; Suzuki \& Hanihara, 1982, Hasegawa, 1980). ${ }^{14} \mathrm{C}$ radiocarbon ages of the fossil beds are 18,250 \pm 650 y.B.P. and 16,600 \pm 30 y.B.P., for Minatogawa vertebrates and Minatogawa man, respectively. These dates correspond to the Würm pleniglacial in the Late Pleistocene. The assemblage is a $C$. astylodon-Manouria fauna with wellpreserved fossil of a variety of endemic vertebrate, including bats, rodents, birds, squamates, tortoises and frogs now living in Okinawa.

2) The island of Tokunoshima in the Amami-oshima insular group has yielded characteristic fossils of terrestrial vertebrates represented by deer and a few other small mammals. They were excavated from the Latest Pleistocene fissure deposits developed in a Ryukyu Limestone sea cliff located in southwest Tokunoshima (Otsuka et al., 1981). This assemblage type was identified as the Kojima vertebrate fossil assemblage by Otsuka (1990), and is composed primarily of the Ryukyu deer (=Cervus astylodon ), Amami-rabbit (= Pentalagus furnessi), two kind of wild rats endemic to the Amami-Oshima (= Diplothrix legata, Tokudaia sp.) and a chelonian (= Manouria sp.). The Dicrocerus ? sp. , which commonly occurs in Late Pleistocene fissure deposits in the Okinawa insular group, is not yet discovered from Tokunoshima. Based on paleontological evidence, it is concluded that the Kojima vertebrate fossil assemblage belongs to the Cervus astylodon-Manouria fauna that migrated to the Central Ryukyu (Okinawa and Amami insular groups) via South Ryukyu during the Early Pleistocene.

Furthermore, bones of $C$. astylodon in this assemblage are much smaller than those from the Okinawa insular group (Otsuka, 1990). Dwarfism of the deer in Tokunoshima could have begun after the separation of Tokunoshima from the Okinawa insular group during the Middle Pleistocene marine transgression that formed the "Ryukyu Coral Sea".

3) In addition, two upper molars of elephants have been recorded from the Late Pleistocene cave deposits at Tanabaru, Ohnogoshi in Miyako Island. They were named, respectively, cf. Paleoloxodon namadicus and Paleoloxodon sp. by Tokunaga (1940) and Otsuka (1941). Due to the paleontological importance of these reports, Japanese paleontologists have expressed varied opinions concerning the systematic position of the fossil molar specimens from Tanabaru. Kamei (1970) regarded them as assignable to the Elephas meridionalis-E. trogonthrii group. Recently, Otuka (1996) claimed that the molar specimen reported by Tokunaga (1940) is referable to Mammuthus shigensis (Matsumoto \& Ozaki), a species that is common in the Early Pleistocene deposits in the Japanese Islands. Judging from the known range of Mammuthus shigensis in the Japanese Islands (Kamei \& Otsuka, 1981), it is possible to that the Late Pleistocene Mammuthus of Miyako and Okinawa Islands are relics of the Early Pleistocene species originally from mainland Japan, which migrated to the other islands only at the time of the Second Land Connection.

\section{DISCUSSION}

As mentioned above, a total of four stratigraphic levels in Ryukyu Islands have yielded fossils of terrestrial vertebrates. Those levels which yield diverse animal assemblages suggest several episodes of land connection between the continent and the islands. Others, yielding a more restricted number of taxa, seems to be composed either of occasional immigrants from the continent during periods of 
A. Second Land Connection

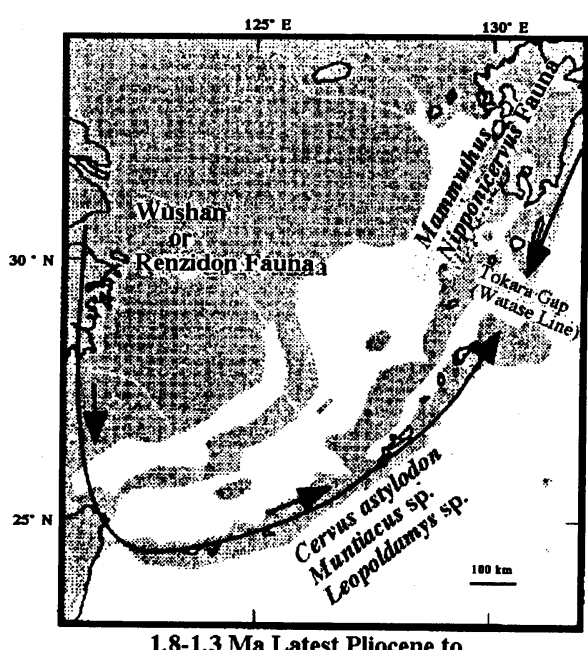
1.8-1.3 Ma Latest Pliocene to
eary Early Pleistocene

\section{Third Land Connection}

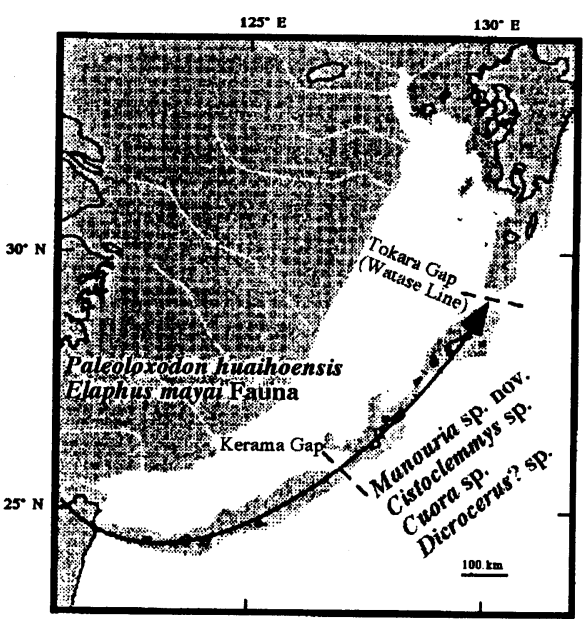

0.20-0.12 Ma late Middle Pleistocene (Age of Urma Movements)

\section{B. Age of Ryukyu Coral Sea}

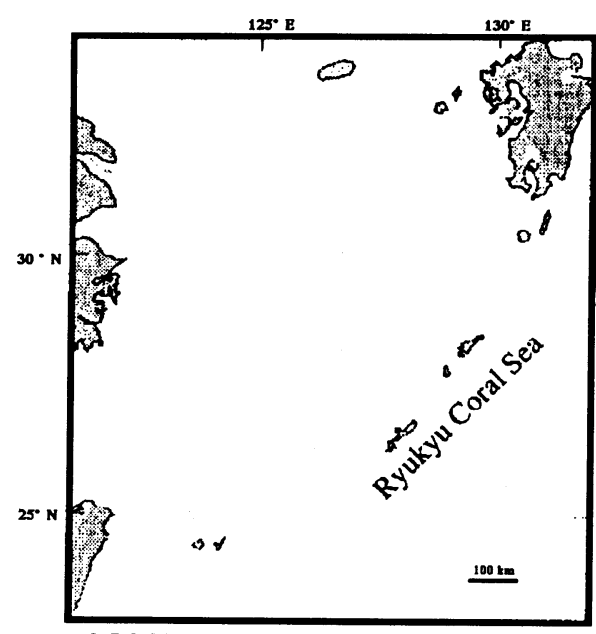

0.5-0.20 Ma middle Middle Pleistocene

\section{Fourth Land Connection}

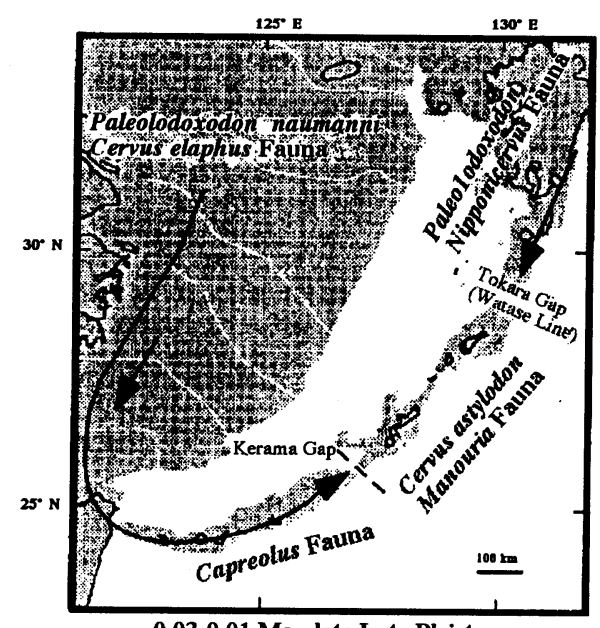

0.03-0.01 Ma late Late Pleistocene

Fig. 3. Migration of terrestrial vertebrates to the Ryukyu Islands. The paleogeographic maps are modified from Kimura (1998).

limited land connection, or declining populations of relic faunas related to proceeding land connections. Abundant fossil faunas are represented by the Imadomari-Akagimata fossil assemblage (Level 2) and the Miyako vertebrate assemblage (Hasegawa, 1980) of South Ryukyu (Level 4). These have more diverse and abundant species compared to Level 3 assemblage, which are relatively limited.

Kimura's (1996a, b) hypothesis explains the mode of changing land configurations in the area of the Ryukyu Islands based on geological data of the islands themselves as well as surrounding 
submarine geology. According to his hypothesis, the Ryukyu Islands formed a long and narrow "Ryukyu Peninsula" stretching northeastward from north Taiwan to the northern end of Central Ryukyu (the Amami insular group) after the last continental stage during Plio-Pleistocene time. This feature was terminated by the formation of the " Ryukyu Coral Sea" (Kizaki \& Oshiro, 1997) at the time of the Middle Pleistocene marine transgression. Furthermore, in the late Middle Pleistocene, the Ryukyu Islands formed the "Ryukyu Peninsula" when the South and Middle Ryukyus were separated by the Kerama Gap.

Kimura's hypothesis is a significant tool to explain the age of migration of the terrestrial vertebrates known in Pleistocene fossil levels in the Ryukyu Islands. Important interpretations are as follows:

1. At an early stage in the Second Land Connection (Latest Pliocene to Early Pleistocene), the Ryukyu Islands were part of the northeastern marginal area of Asia. During this age, the ancestral forms of the Ishikawa's frog and Mammuthus could have migrated through this marginal area (Fig. 3, A).

2. After the regression of the Shimajiri Sea, a portion of the Renzidong Fauna or the Wushan Fauna of Central China represented by Cervus (Metacervulus) and Leopoldamys migrated to the Ryukyu Peninsula and reached the Amami insular group of Central Ryukyu. They could not go further northward due to the existence of the Tokara Gap (The third Land Connection; Fig. 3, A). In the Middle Pleistocene, the peninsula was extensively transgressed by the "Ryukyu Coral Sea" , and, for that reason, the terrestrial vertebrates moved toward the highland area of islands of Iriomote, Ishigaki, Okinawa, Tokunoshima and Amami-oshima (Fig. 3, B).

3. In the late Middle Pleistocene, the regression of the "Ryukyu Coral Sea" resulted in the creation of the second stage of the "Ryukyu Peninsula", extending from Taiwan to Central Ryukyu. Over this land connection, Manouria sp., Cistoclemmys sp. and Dicrocerus? sp. were able to migrate to the "Ryukyu Peninsula" and finally reach the Amami insular group of North Ryukyu (Third Land Connection) (Fig. 3, C).

4. At the time of the Fourth Land Connection during the latest Pleistocene, the Ryukyu Islands were separated into two mainlands by the Kerama and Tokara Gaps (straits). At this point, members of the terrestrial vertebrate fauna of northeastern Asia, represented by roe deer (= Capreolus miyakoensis) and wild cat (= Felis sp.), arrived on the island of Miyako. On the other hand, the descendants of the earlier immigrants, such as Cervus astylodon, Dicrocerus? sp., Manouria sp., Cistoclemmys sp. and Cuora sp., flourished over the Central Ryukyu islands forming a characteristic $C$. astylodon-Manouria fauna. These large mammals and tortoises, however, became completely extinct at the end of the Late Pleistocene, whereas other small mammals represented by rodents, amphibians and reptiles are still living in Central Ryukyu forming the characteristic endemic fauna of the Ryukyu Islands (Ota, 1998).

Recently, Ota (1998) presented paleogeographic maps of the Ryukyu Islands during the Pleistocene (Kizaki \& Oshiro's hypothesis), modified after Hikida \& Ota (1997). He developed these paleogeographic maps from the study of geographic patterns of endemism and speciation in amphibian and reptiles found in the Ryukyu Islands. According to Ota's hypothesis, the Ryukyu Islands in the Early Pleistocene formed a "peninsula" from Taiwan to South Ryukyu (including the Miyako insular group), whereas the area of Central Ryukyu, comprising the Okinawa and Amami insular groups, formed a separate land mass that has never been connected to South and North Ryukyu 
at any time.

Judging from Ota's hypothesis, the living endemic amphibian and reptilian fauna of Central Ryukyu is the oldest in the Ryukyu Islands, and can be traced back to the Early Pleistocene. In contrast, the herp fauna of the Yaeyama insular group (Ishigaki and Iriomote) of South Ryukyu would have originated in the Middle Pleistocene.

If Ota's hypothesis is correct, the migration of the Cervus (Metacervulus)-Leopoldamys fauna from Central China to Central Ryukyu must have have taken place before the Early Pleistocene. In this regard, it is difficult to explain the northward expansion of terrestrial vertebrate fauna at the time of Third Land Connection during the Middle Pleistocene and the migration of Asian mainland terrestrial vertebrates to South Ryukyu in the latest Pleistocene.

Four stages of land connection as "migration routes" of terrestrial vertebrates are proposed (Fig. 3, A D) in this study, based on the occurrence of fossil vertebrate assemblages from four fossil levels in the Ryukyu Islands.

\section{CONCLUSION}

Interpretations and discussions provided above lead to the following conclusions:

1. In the Ryukyu Islands, fossil assemblages of terrestrial vertebrates occur at four major stratigraphic levels, ranging from the latest Miocene to latest Pleistocene. These fossil assemblages represent successful colonizations by taxa that migrated from the Asian mainland during the past four land connections. 2. The Imadomari-Akagimata assemblage from Level 2 (Early Pleistocene) on Okinawa island is the oldest and one of the most important Pleistocene fossil assemblages in the Ryukyu Islands. It is considered to be a faunal extension of either the Plio-Pleistocene Renzidon fauna in Anhui Province or the Wushan fauna in Sichuan Province, both located in Central China, components of which migrated to Okinawa islands at the time of the second land connection. 3 . Among the vertebrates in the Imadomari-Akagimata assemblage, the archetypal deer (= Cervus (Metacervulus) flourished in the islands during the Pleistocene, together with other immigrants of the third land connection such as Dicrocerus? sp. and large tortoise (= Manouria sp.). These taxa became completely extinct at the end of Pleistocene (ca. 15,000 years B.P.), after the formation of many morphotypes. It can be said that other animals in this assemblage may serve as the progenitors of the present mammals, reptiles, and amphibians living in the Ryukyu Islands.

ACKNOWLEDGMENTS I wish to express my indebtedness to the following people: Mr. Ki'ichi Maja in Ginowan, Okinawa who gave valuable information about fossil vertebrates in Okinawa and helped me in the excavation of fossil beds; the late Mr. Seiho Oyama, Mr. Chokei Kishaba and Mr. Seikou Oyama of Naha, Okinawa who provided much-needed assistance during my entire stay in Okinawa; Mr. Yukihide Matsumoto who advised me on the paleontological problems on deer, from the Ryukyu Islands. Great appreciation is given to Dr. Ross D. E. MacPhee and Dr. Clare Flemming of the Department of Mammalogy, American Museum of Natural History and Mr. Edwin M. Mojares of the Department of Earth and Environmental Sciences, Kagoshima University for their critical reading of the manuscript. Sincere thanks is due to Professor Mitsuru Hotta, dean of Faculty of Kagoshima University, for his kind cooperation in publishing the papers of the the present proceeding. 


\section{REFERENCES}

Aiba, J. \& Sekiya, E., 1979. Distribution and characteristics of the Neogene sedimentary basins around the Nansei-shoto (Ryukyu Islands). Jour. Jap. Assoc. Petro. Tech. 44 (5): 229-340. (in Japanese)

Blow, W. H., 1969. Late Middle Eocene to Recent planktonic foraminiferal biostratigraphy. In: Bronnimann, P., \& H. H. Renz, eds., Proceedings of the First International Conference on Planktonic Microfossils, Leiden, E. J. Brill. 1: 199-421.

Brauns, D., 1884. Bemerkungen über die geographische Verbreitung der Säugethiere Japans. Mitt. Ver. f. Erdkunde 2, Halle, 85-114.

Hanzawa, S., 1935. Topography and geology of the Riukyu Islands. Sci. Rep. Tohoku Imp. Univ., 2nd Ser. 17: pp. 1-61.

Hasegawa, Y., 1980. Notes on vertebrate fossils from Late Pleistocene to Holocene of Ryukyu Islands, Japan. Quaternary Res. (Daiyonki Kenkyu) 18 (4): 263-267. (in Japanese with English abstract)

, 1985. Note on Carnivora, Chiroptera and larger rat (Diplothrix legata) from Pinza-Abu Cave, Miyako Island, Okinawa, Japan. In: Department of Education, Okinawa Prefecture Government, ed., Reports on Excavation of the Pinza-Abu Cave, pp. 83-91. (in Japanese)

- Otsuka, H. \& Nohara, T. 1973., Fossil vertebrates from the Miyako Island (Studies of the Paleovertebrates Fauna of Ryukyu Islands, Japan. Part 1. Mem. Nat. Sci. Mus. no. 6: 40-52. (in Japanese with English abstract)

\& Oshiro, I., 1981. Antler's Fossils of Dicrocerus sp. from Maya-Abu Cave, Ginowan-City, Okinawa, Japan. Abst. 88th Ann. Meeting Geol. Soc. Japan, p. 281. (in Japanese)

Hayashi,Y., 1985. Larger wild boar from Pinza-Abu Cave, Miyako Island, Okinawa, Japan. In: Department of Education, Okinawa Prefecture Government, ed., Reports on Excavation of the Pinza-Abu Cave, pp. 75-78. (in Japanese)

Honda, N., Tsuji, Y., Matsuda, H., Sado, K . \& Yuki, T., 1993. Carbonate sedimentation and depositional enviroments of the Pleistocene Ryukyu Group in Irabu Islands, Ryukyus, SW Japan. Rep. Techn. Res. Centr., J.N.O.C. no. 24: 123-151.

$\longrightarrow,-1994$. Sea level changes and development of the Pleistocene Ryukyu Group in the Irabu Island region, southwest Japan. Jour. Jap. Assoc. Petr. Techn. 59 (1): 86-98.

Hikida, T. \& Ota, H., 1997. Biogeography of reptiles in the subtropical East Asian islands. In: Lue, K. Y. \& Chen, T. H., eds., Proceedings of the Symposium on the Phylogeny, Biogeography and Conservation of Fauna and Flora of East Asian Region, pp. 11-28. National Science Council, Taipei.

Honda, N., Tsuji, Y., Matsuda, H., Sado, K. \& Yuki, T., 1993. Carbonate sedimentation and depositional environments of the Pleistocene Ryukyu Group in Irabu Island, Ryukyus, SW Japan. Rep. Techn. Res. Centr. J. N. O. C. no. 24: 123-151.

Honda, N., Tsuji, Y. \& Matsuda, H., 1994. Sea level changes and development of the Pleistocene Ryukyu Group in the Irabu Island region, southwest Japan. Jour. Jap. Assoc. Petr. Techn. 59 (1): 86-98.

Huang, W., 1998. Is Africa the only birthplace of man ? Beijing Rev. 42 (31): 12- 15.

, 1999. A message from early man: New finds from research on the early and middle Paleolithic of China. Jap. Archeol. 8: 1-16. (in Japanese and Chinese) 
— Fang, Q., Chi, H. \& Zheng, S., 1991. Wushan Hominid Site, 199 pp. Haiyan Pub., Beijing, China.

Iturralde-Vinent, M. A. \& MacPhee, R. D. E., 1999. Paleogeography of the Caribian region: implications for Cenozoic biostratigraphy. Amer. Mus. Nat. Hist. Bull. 238: 1-95.

Jin, C. Z. \& Zheng. L. 1998. Evidence of early Pleistocene human activity discovered from Fanchan country, Anhui Province, China. Quat. Sci. no. 4: 1-2. (in Chinese)

- Han L. \& Wei, K., 1999. Early Pleistocene Paleolithic discovered from the Renzidong ruins in Fanchang county, Anhui. Acta Anthropol. Sinica 18 (1): 70-71. (in Chinese)

Kamei, T., 1970. Horizon of the elephant fossil in Miyoko Island. Tsukumo-Chigaku no. 5: 1-8. (in Japanese)

— \& Otsuka, H., 1981. The Plio-Pleistocene stratigraphy of Japan in relation to Proboscidean evolution. Proceedings of Neogene / Quaternary Boundary Field Conference, India, pp. 83-88.

Kaneko, N. \& Ito, T., 1995. Strontium isotopic composition of basal part of the Ryukyu Group, in southern Okinawa Island, southwest Japan. Abstract of the 102th Annual meeting of the Geological Society of Japan (Hiroshima Univ.), p. 116. (in Japanese)

Kaneko, Y., 1985. On some fossils of Microtinae Rodents from Pinza-Abu Cave, Miyako Island, Okinawa, Japan. In: Department of Education, Okinawa Prefecture Government, ed., Reports on Excavation of the Pinza-Abu Cave, pp. 93-113. (in Japanese)

Kawashima, Y., Ishimine, D. \& Oyama, S., 1985. Comparison of the Teeth between the Ryukyu wild boar and the wild boar from Pinza-Abu Cave, Miyako Island, Okinawa, Japan. In: Department of Education, Okinawa Prefecture Government., ed., Reports on Excavation of the Pinza-Abu Cave, pp. 79-82. (in Japanese)

Kimura, M., 1996a, Quaternary paleogeography of the Ryukyu Arc. Jour. Geogr. 105: 259-285. , 1996b, Paleogeography of the Ryukyu Arc. Chikyu Monthly 18: 488-494. (in Japanese)

, 1998. Paleogeography of the Ryukyu Islands. In: Otsuka, H., ed., Programme and Abstract of an International Symposium: The Ryukyu Islands - The Arena of Adaptive Radiation of Island Fauna, pp. 9-10. Kagoshima University, Kagoshima.

Kizaki, K. \& Oshiro, I., 1977. Paleogeography of the Ryukyu Islands. Kaiyou Monthly 9: 38-45. (in Japanese)

MacNeil, F. S., 1960. Tertiary and Quaternary Gastropoda of Okinawa. U. S. G. S. Prof. Paper 339, 148 pp.

Natori, H., 1976. Planktonic foraminiferal biostratigraphy and datum planes in the Late Cenozoic sedimentary sequence in Okinawa-jima, Japan. In: Takayanagi, Y. \& Saito, T., eds., Progress in Micropaleontology, pp. 214-243, 6 pls. Amer. Mus. Nat. Hist., New York.

Noda, H., 1971. New Anadarid and associated molluscan fauna from the Haneji Formation, Okinawajima, Ryukyu islands. Trans. Proc. Palaeont. Soc. Japan, N. S. no. 81: 27-51, 2pls.

Nohara, T. \& Hasegawa, Y., 1973. An elephant tooth from Kyan, Okinawa-jima (Studies of the Paleovertebrates fauna of Ryukyu Islands, Japan). Part III. Mem. Nat. Sci. Mus. Tokyo no. 6: 59-63. (in Japanese with English abstract)

- Akena, H. \& Shimoji, K., 1997. Fossil mammals from Urasoe City, Okinawa. Bull. Coll. Educ. Univ. Ryukyus no. 51: 113-132. (in Japanese with English abstract)

, Chinen, S. \& Kishaba, C., 1999. Fossil deer from Kuniyoshi, Itoman City, Okinawa. Bull. Coll. Educ. Univ. Ryukyus, no. 54: 373-410, 10 pls. (in Japanese with English abstract) 
Okada, Y., 1927, A study on the distribution of tailless batrachians of Japan. Annot. Zool. Jap. 11: 137-143.

Okinawa Quaternary Research Group, 1976. Quaternary System of Okinawa and Miyako Gunto, Ryukyu Islands-Especially on the stratigraphy of "Ryukyu Limestone". Chikyu Kagaku (Earth Science), 30: 145-162. (in Japanese with English abstract)

Oshiro, I., 1994. Terrestrial vertebrate fossils from the Futenma-gu Site, Ginowan City, Okinawa, Japan. Jour. Geogr. 103 (1): 49-63. (in Japanese with English abstract)

— \& Nohara, T., 1977. The occurrence of fossil deer in the Ryukyus. Bull. Okinawa Pref. Mus. no. 3: 1-10. (in Japanese)

Ota, H., 1998. Geographic patterns of endemism and speciation in amphibians and reptiles of the Ryukyu Archipelago, Japan, with special reference to their paleogeographic implications. Res. Popul. Ecol. 40 (2): 189-204.

Otsuka, H., 1978. On the fossil elephant dredged from East China Sea. In: Kizaki, K., ed., Geological Studies of the Ryukyu Islands 3: 149-156. (in Japanese)

, 1980 . Fossil vertebrates from the Ryukyu Islands. Iden (Genetics) 34 (19): $46-55$ (in Japanese).

- 1983. The Cenozoic vertebrate fauna of Kyushu and the Ryukyu Islands, west Japan, viewed from the faunal relation to those of the Asiatic continent. In: Shuto, T., Aihara, A., Sakai, K. \& Sano, H., eds., Geological Development of the Kyushu Island with Special Reference to Relation of Island Arcs and Continent, p. 119. Spec. Pub. Comm. Nishinihon Branchi, Geol. Soc. Jap. (in Japanese with English abstract)

$\longrightarrow$ 1988. Early and Middle Pleistocene Stratigraphy in Kyushu and Ryukyu, Japan. Mem. Geol. Soc. Japan, no. 30: 155-168. (in Japanese)

- 1990. Fossil deer from the Tokuno-shima, Ryukyu Islands, Southwest Japan. Mem. Nat. Sci. Mus., Tokyo no. 23: 185-194. (in Japanse with English abstract)

, 1990. The mammalian fossils in the Katanoyama fossil assemblage. In: Otsuka, H. ed., First Report on the Excavation of the Katanoyama Fossil Assemblage in Nishino-omote City, pp. 13-17. The Board of Education of Nishino-omote City.

, 1996. On the fossil elephant from the Miyako island of the Nansei islands. Proceeding of the Nishinihon Branch, Geological Society of Japan no. 108: 26.

, 1998. Pleistocene vertebrate fauna in the Ryukyu Islands: Its dispersal and extinction. In: Otsuka, H., ed., Programme and Abstract of an International Symposium: The Ryukyu IslandsThe Arena of Adaptive Radiation of Island Fauna, pp. 11-14. Kagoshima University, Kagoshima.

\& Hasegawa, Y., 1973. Fossil deer from Ishigaki Island (Studies of the paleovertebrate fauna of the Ryukyu Islands, Japan. Part II). Mem. Natn. Sci. Mus. Tokyo no. 6: 53-58. (in Japanese with English abstract)

- Horiguchi, H. \& Nakagawa, H., 1981. On the fossil deer discovered from Tokunoshima, Ryukyu Islands. In: Kizaki, K., ed., Geological Studies of the Ryukyu Islands 5: 49-54. (in Japanese with English abstract)

\& Nakamura, H., 1990. The first and the second excavations of the Katanoyama fossil assemblage. In: Otsuka, H., ed., First Report on the Excavation of the Katanoyama Fossil Assemblage in Nishino-omote City, pp. 2-4. The Board of Education of Nishino-omote City.

\& Noro, T., 1990. On the geology of Tanegashima and the Katanoyama Formation. In: Otsuka, H., ed., First Report on the Excavation of The Katanoyama Fossil Assemblage in Nishino-omote 
City, 5-13. The Board of Education of Nishino-omote City.

\& Kuwayama, R., 2000. Fossil frog excavated from the Lower Pleistocene deposits of Tanegashima Island and its paleobiological significance. Jour. Geol. Soc. Japan 106 (6): 1-17.

Otuka, Y., 1941. On the stratigraphic horizon of Elephas from Miyako Is., Ryukyu Islands, Japan. Proc. Imp. Acad. Tokyo 18 (2): 43-47.

Saito, T., 1984. Planktonic foraminiferal datum planes for biostratigraphic correlation of Pacific Neogene sequences -1982. Status Report. In: Ikebe, N. \& Tsuchi, R. eds., Pacific Neogene datum planes. Contributions to biogeography and chronology, pp. 3-10. Univ. Tokyo Press.

Shikama, T. \& Otsuka, H., 1971. Land bridge in East China Sea. In: Nasu N., ed., Symposium on Geological Problems of the Kyushu and its Neigbouring Sea Area, 131-139. Geological Society of Japan, Kyushu Univ. (in Japanese)

Suzuki, H., 1975. Discoveries of the fossil man from Okinawa Island. Jour. Anthrop. Soc. Nippon 83: 113-124. (in Japanese with English abstract)

— \& Hanihara, K., eds., 1982. The Minatogawa Man, 208 pp., 68 pls. University of Tokyo Press, Tokyo.

Takahashi, A. \& Otsuka, H., 1998. Fossil chelonians from the Ryukyu Islands. In: Otsuka, H., ed., Programme and Abstract of an International Symposium: The Ryukyu Islands- The Arena of Adaptive Radiation of island Fauna, pp. 61-64. Kagoshima University, Kagoshima.

Takai, F. \& Hasegawa, Y., 1971. On the vertebrate fossils of the Ryukyu Islands. In: Nasu N., ed., Symposium on Geological problems of the Kyushu and its neigbouring sea area, 107-109. Geological Society of Japan, Kyushu Univ. (in Japanese)

Tanaka, Y. \& Ujiie, H., 1984. A standard Late Cenozoic Micropaleontology in southern Okinawajima, Japan. Bull. Nat. Sci. Mus. 10 (4): 141-164.

Tokunaga, S., 1940. A fossil elephant tooth discovered in Miyakozima, an island of the Ryukyu Archipelago, Japan. Proc. Imp. Acad. Tokyo 13 (2): 43-47.

— Takai, F., 1939. A study of Metacervulus astylodon (Matsumoto) from the Ryukyu Islands, Japan. Trans. Biogr. Soc. Japan 3: 221-248.

Tomida, Y. \& Otsuka, H., 1993. First discovery of fossil Amami rabbit (Pentalagus furnessi) from Tokunoshima, southwestern Japan. Bull. Nat. Sci. Mus., Ser. C (Geol. \& Paleont.), 19 (2): 93-97.

Uemura, K., 1990. Fossil flora in the Katanoyama fossil assemblage. In: Otsuka, H., ed., First Report on the Excavation of the Katanoyama Fossil Assemblage in Nishino-omote City, pp. 23-26. The Board of Education of Nishino-omote City.

Ujiie, H., 1985. A standard Late Cenozoic microbiostratigraphy in southern Okinawa-jima, Japan. Part 2, Details on the occurrence of planktonic foraminifera with some taxonomic annotations. Bull. Natn. Sci. Mus., Tokyo, Ser. C, 11: 103-116.

\& Oki, K., 1974. Uppermost Miocene-Lower Pleistocene planktonic foraminifera from the Shimajiri Group of Miyako-jima, Ryukyu Islands. Mem. Nat. Sci. Mus. Tokyo no. 7: 31-52.

Yabumoto, Y. \& Ueno, T., 1990. Fossil fishes in the Katanoyama fossil assemblage. In: Otsuka, H., ed., First Report on the Excavation of the Katanoyama Fossil Assemblage in Nishino-omote City, pp. 17-21. The Board of Education of Nishino-omote City.

Wallace, A. R., 1876. The Geographical Distribution of Animals, vol. 1., 503 pp. MacMillan and Co., London. 
Zhen, B. \& Hasegawa, Y., 1985. Capreolus remains, its systematics and paleobiological probrems of Pinza-Abu Cave, Miyako Island, Okinawa, Japan. In: Reports on Excavation of the Pinza-Abu Cave, pp. 33-73, 8 pls. Department of Education, Okinawa Prefectural Government. (in Japanese)

\section{大塚裕之・高橋亮雄＼cjkstart琉球列島における更新世脊椎動物相 : その渡来と絶滅}

琉球列島には，多くの陸棲脊椎動物の化石種が産出する他，現在でも数多くの固有種が棲息しており，世 界の島嶼域における陸棲脊椎動物の進化の研究にとって重要なフィールドの一つである。これら化石およ び現生の陸棲脊椎動物群集は, 新第三紀中新世末期以降更新世後期までの, 少なくとも 4 回の陸繋期に, それぞれ大陸から渡来し, 島嶼での繁栄の後, 更新世末期に一斉絶减した種や, 絶减を免れた種の子孫で ある現生の固有種から成る。それらの分布および種構成は, 同列島と大陸との陸繋状態, とくに生物分布 境界線としての渡瀬線が通るところとして知られるトカラ・ギャップ (トカラ海峡) やケラマ・ギャップ の形成時期に密接に関連している。近年の琉球列島における脊椎動物化石およびそれらの包含層の地質学 的・古生物学的研究成果は, 同列島の化石および現生動物群集の渡来時期ならびにそれらの起源について 重要な手がかりを与えた他, 島嬹への隔離がもたらす陸棲脊椎動物のサイズの変化のテンポおよびモルフ オタイプの形成過程についての重要なデー夕を提供した。

琉球列島における鮮新世以降の陸棲脊椎動物化石群集は, 中新統最上部の層準を除くと, 鮮新統および 更新統のほぼ 4 つ層準から産出する。

1）鮮新世末期から更新世初期の第 2 陸繫期 (1.8 - $1.5 \mathrm{Ma})$ には, 琉球弧一帯は台湾北部から奄美諸島ま でのびる一大半島を形成した。この陸地を通って，大陸は中国中部の四川省巫山または安徽省繁昌の揚子 江下流域から, シカやネズミ類によって特徴づけられる動物群が琉球列島へ渡来し, 第 2 層準のリュウキ ユウジカーレオポルダミス動物群 (Cervus astylodon - Leopoldamys fauna) (今泊一赤木又化石群集; 1.5 $1.3 \mathrm{Ma}$ ) を形成した。それらの一部は中琉球の奄美諸島まで達したが，この時既に形成されていたトカラ 海峡によって, 北琉球 (大隅諸島) へは到達出来なかった。一方, 種子島の増田層形之山部層 $(1.3 \pm 0.2$ Ma) からは中琉球の固有種であるイシカワガエル化石を産出するが, その先祖の北琉球（種子島）への渡 来は, 増田層を堆積せしめ, トカラ海峡（渡瀬線）を形成した約 130 万年前の海進以前に存在した陸地を 通って行われたであろう。

2）第 3 陸繋期 (ca. $0.02 \mathrm{Ma}$ ) は, 更新世中期に広がった琉球サンゴ海の隆起や傾動運動（ウルマ変動）, さらにその後の侵食によって生じた台湾から中琉球の奄美諸島まで連なった半島にそって, 大型リクガメ 類のオオヤマリクガメ(Manouria sp.), リュウキュウヤマガメ(Geoemyda japonica) やハコガメ類 (Cistoclemmys), 古型 Munticinea のリュウキュウムカシキョン Dicrocerus ? sp. などが南から渡来した 可能性がある。

3）ウルム水期にあたる第 4 陸繋期には, 台湾北西部から八重山・宮古諸島までの南琉球は大陸と陸地接 続し, 北方系の動物群集である Capreolus 動物群の渡来があった。これらは, 更新世前一中期までに渡来 していた動物群の子孫と混在した第 4 層準の宮古脊椎動物化石群として認められる。

この時期には, 中琉球 (沖縄諸島および奄美諸島) は, 北琉球 (大隅諸島) および南琉球とは陸地接続 は無かったか，あるいは不完全で，第 2 および第 3 陸繋期に渡来した動物群の遺存種から成る更新世末期 のリュウキュウジカーオオヤマリクガメ動物群 (Cervus astylodon - Manouria fauna) を形成した。これら の動物群は琉球石灰岩裂罅や洞窟堆積物（第 4 層準）から産出する。その中で, リュウキュウジカ $(C$. astylodon) やリュウキュウムカシキョン (Dicrocerus? sp.) 等のシカ類や大型リクガメ (Manouria sp.) は更新 世末 (0.025-0.015 Ma) に一斉絶减したが, この時代に絶减を免れたその他の哺類乳・爬虫類・両生類の子孫 は, 現在の琉球列島の固有種を形成している。 